\title{
Pengaruh Dosis Rhizobium Serta Macam Pupuk NPK Terhadap Pertumbuhan Tanaman Kedelai (Glycine max) Varietas Anjasmoro
}

\author{
Arina Manasikana1, Lianah', Kusrinah'1 \\ ${ }^{1}$ Program Studi Biologi, Fakultas Sains dan Teknologi, UIN Walisongo Semarang \\ Email: ${ }^{1}$ arinamanasikana272@gmail.com, ${ }^{2}$ lianahkuswanto@walisongo.ac.id, \\ 3 kusrinah@walisongo.ac.id
}

\begin{abstract}
Efforts to increase the growth and yield of soybean plants can be done through the use of cultivation technology, namely by providing biological fertilizer treatments such as $N$-fixing bacteria, namely Rhizobium. The study aims to determine the effect of the right Rhizobium dose and type of NPK fertilizer on the growth of the Anjasmoro variety of soybean (Glycine max). This research uses a factorial randomized block design with two factors and three repetitions. The first factor is Rhizobium inoculation consisting of I0: No inoculum, I1: Rhizobium inoculum (5 g/ kg seed), I2: Rhizobium inoculum (7 g / kg seed), I3: Rhizobium inoculum $(9 \mathrm{~g} / \mathrm{kg}$ seed). The second factor is the type of NPK fertilizer, namely P0: No fertilizer, P1: solid NPK fertilizer $(0.8 \mathrm{~g} /$ plant), P2: liquid NPK fertilizer. The results showed that the dose of Rhizobium that could affect soybean growth was a dose of 9 grams $/ \mathrm{kg}$ of seed that significantly affected the number of leaves and leaf color but did not significantly affect plant height, number of branches, number of root nodules and root nodules weight. NPK fertilizer that can affect soybean growth is liquid NPK fertilizer, and only has a significant effect on leaf color. The interaction of Rhizobium inoculation treatment and NPK fertilizer types significantly affected most parameters but did not significantly affect the number of branches and weight of root nodules.
\end{abstract}

Keywords: Rhizobium inoculation, NPK fertilizer, soybean growth

\section{Pendahuluan}

Kedelai merupakan komoditas terpenting ketiga setelah padi dan jagung. Kedelai merupakan komoditas palawija yang kaya akan protein nabati, protein yang dibutuhkan dalam peningkatan gizi masyarakat karena baik bagi kesehatan dan juga relatif lebih murah (Misran 2013).

Kedelai memiliki banyak varietas, pada tahun 2016 pemerintah melepas 86 varietas unggul kedelai. Salah satu varietas unggul kedelai yaitu varietas Anjasmoro. Anjasmoro merupakan salah satu varietas unggul kedelai yang dapat beradaptasi pada ekosistem pertanian lahan sawah, lahan kering, lahan rawa lebak dan lahan rawa pasang surut. Beberapa keunggulan yang dimiliki varietas anjasmoro yaitu memiliki produksi tinggi, tahan rebah, moderat terhadap penyakit daun, bijinya besar, polongnya tidak mudah pecah dan terutama untuk bahan pembuatan tempe (Jumakir dan Endrizal 2014).

Nitrogen $(\mathrm{N})$ termasuk unsur makro yang penting bagi pertumbuhan tanaman, namun ketersediaan $\mathrm{N}$ di daerah tropis seperti Indonesia tergolong rendah. (Hendriyanto et al. 2017). Menurut (Fitriana et al. 2014), bakteri Rhizobium bersimbiosis dengan tanaman legum, kelompok bakteri ini akan menginfeksi akar tanaman dan membentuk bintil akar di dalamnya. Bakteri Rhizobium hanya dapat memfiksasi nitrogen atmosfer bila berada di dalam bintil akar dari mitra legumnya.

Beberapa masalah yang dihadapi dalam meningkatkan pertumbuhan kedelai saat ini adalah pada teknik budaya, kondisi tanah dan 
kondisi lingkungan. Untuk memperbaiki produksi dan pertumbuhan kedelai dapat dilakukan perbaikan pada teknik budidayanya, salah satunya yaitu pemberian unsur hara tanaman sebagai unsur hara pendukung kesuburan tanah.

\section{Metode}

Penelitian ini dilaksanakan di Desa Sendangwungu, kabupaten Blora. Alat dan bahan yang digunakan dalam penelitian ini antara lain: polybag ukuran $20 \times 30$, timbangan analitik, alat semprot (sprayer), biji kedelai varietas Anjasmoro yang diperoleh dari Kelompok Tani Sido Mulyo Kabupaten Blora, Rhizobium dalam bentuk pupuk hayati, pupuk NPK padat, pupuk NPK cair, tanah, kedelai varietas Anjasmoro. Penilitian ini menggunakan Rancangan Acak Kelompok (RAK) faktorial dengan dua faktor dan tiga kali pengulangan. Faktor pertama yaitu inokulasi Rhizobium terdiri dari $\mathrm{I}_{0}$ : Tanpa inokulum, $\mathrm{I}_{1}$ : Inokulum rhizobium (5 $\mathrm{g} / \mathrm{kg}$ benih), $\mathrm{I}_{2}$ : Inokulum rhizobium (7 $\mathrm{g} / \mathrm{kg}$ benih), $\mathrm{I}_{3}$ : Inokulum rhizobium ( $9 \mathrm{~g} / \mathrm{kg}$ benih). Faktor kedua adalah jenis pupuk NPK, yaitu $\mathrm{P}_{0}$ : Tanpa pupuk, $\mathrm{P}_{1}$ : pupuk NPK padat $(0,8 \mathrm{gr} /$ tanaman $), \mathrm{P}_{2}$ : pupuk NPK cair. Dilakukan tiga kali ulangan sehingga terdapat 36 polybag. Pengamatan dilakukan pada umur 14 HST, 28 HST, 42 HST, 56 HST. Jumlah nodul akar dihitung ketika kedelai berumur 56 HST. Parameter pengamatan meliputi jumlah daun, warna daun, tinggi tanaman, jumlah cabang, jumlah nodul akar dan berat nodul akar.

Cara kerja penelitian ini yaitu mempersiapkan tanah yang dimasukkan pada masing-masing polybag. Inokulasi Rhizobium dengan cara pelapisan pada biji kedelai dengan bubuk Rhizobium. Biji kedelai sebelumnya diberi sedikit air dan ditambahkan gula. Kemudian diaduk hingga rata. Sebanyak 3 biji ditanam, pada setiap polybag dengan kedalaman lubang tanam $\pm 2 \mathrm{~cm}$. Pengurangan tanaman dilakukan setelah satu minggu setelah tanam, dengan meninggalkan 2 tanaman yang paling baik pertumbuhannya. Aplikasi pupuk NPK diberikan pada umur $14,24,34,44$, dan 54 hari setelah tanam (HST).

\section{Analisis Data}

Data pengamatan yang diperoleh dianalisis dengan menggunakan Two Way Analisis of Varian (ANOVA) dengan derajat kepercayaan $95 \%(p<0,05)$ untuk mengetahui pengaruh perlakuan. Hasil analisis ragam yang nyata dilanjutkan dengan uji Tukey pada taraf nyata $5 \%$ untuk mengetahui perbedaan diantara perlakuan.

\section{Hasil dan Pembahasan Jumlah Daun}

Hasil pengamatan setelah dianalisis secara statistik menunjukkan berpengaruh tidak nyata pada perlakuan dosis inokulasi Rhizobium terhadap jumlah daun pada 15, $30 \mathrm{HST}$, tetapi berpengaruh nyata pada 45 HST. Sedangkan pupuk NPK berpengaruh tidak nyata pada 15, 30 dan 45 HST. Interaksi antar perlakuan dosis inokulasi Rhizobium dan pupuk NPK memberikan pengaruh yang nyata pada 15,30 dan 45 HST (Tabel 1).

Gambar 1. menunjukkan bahwa pada 15, 30 dan 45 HST, jumlah daun mengalami penambahan. Pada 15 jumlah daun terbanyak pada kombinasi taraf perlakuan I0P1 HST(10,333), 30 HST jumlah terbanyak pada kombinasi I0P1 (22,667), dan pada 45 HST jumlah terbanyak pada kombinasi IOP0 $(48,000)$.

\section{Warna Daun}

Hasil pengamatan setelah dianalisis secara statistik menunjukkan ada pengaruh yang nyata perlakuan dosis inokulasi Rhizobium dan pupuk NPK terhadap warna daun pada 15, 30 HST. Interaksi antar perlakuan dosis inokulasi Rhizobium dan pupuk NPK juga memberikan pengaruh nyata pada 15, 30 HST. Namun ketiga perlakuan tidak memberikan pengaruh nyata pada 45 HST (Tabel 2).

Gambar 2. Menunjukkan bahwa pada 15 HST warna daun yang bagus terdapat pada kombinasi taraf perlakuan I2P2 (7488), 30 HST pada kombinasi I2P0, I2P1 dan I2P2 (7739), dan pada 45 HST pada kombinasi I1P2 (7738). 
Tabel 1. Hasil uji beda rataan interaksi inokulasi Rhizobium dan pupuk NPK terhadap jumlah daun

\begin{tabular}{clll}
\hline \multirow{2}{*}{ Perlakuan } & \multicolumn{3}{c}{ Jumlah daun } \\
\cline { 2 - 4 } & 15 HST & \multicolumn{1}{c}{$30 \mathrm{HST}$} & \multicolumn{1}{c}{$45 \mathrm{HST}$} \\
\hline I0P0 & $9,667 \mathrm{~b}$ & $19,667 \mathrm{ab}$ & $48,000 \mathrm{~b}$ \\
I0P1 & $10,333 \mathrm{~b}$ & $22,667 \mathrm{~b}$ & $44,000 \mathrm{~b}$ \\
I0P2 & $9,333 \mathrm{ab}$ & $16,333 \mathrm{ab}$ & $37,333 \mathrm{abc}$ \\
I1P0 & $7,333 \mathrm{ab}$ & $19,000 \mathrm{ab}$ & $38,667 \mathrm{bc}$ \\
I1P1 & $9,667 \mathrm{~b}$ & $19,667 \mathrm{ab}$ & $39,667 \mathrm{~b}$ \\
I1P2 & $6,333 \mathrm{ab}$ & $15,000 \mathrm{a}$ & $19,000 \mathrm{a}$ \\
I2P0 & $7,667 \mathrm{ab}$ & $17,000 \mathrm{ab}$ & $31,667 \mathrm{ab}$ \\
I2P1 & $7,333 \mathrm{ab}$ & $18,667 \mathrm{ab}$ & $33,667 \mathrm{ab}$ \\
I2P2 & $9,000 \mathrm{ab}$ & $21,667 \mathrm{~b}$ & $38,000 \mathrm{abc}$ \\
I3P0 & $9,333 \mathrm{ab}$ & $20,333 \mathrm{ab}$ & $43,000 \mathrm{~b}$ \\
I3P1 & $5,000 \mathrm{a}$ & $19,000 \mathrm{ab}$ & $20,000 \mathrm{a}$ \\
I3P2 & $9,667 \mathrm{~b}$ & $19,333 \mathrm{ab}$ & $34,667 \mathrm{ab}$ \\
\hline
\end{tabular}

Keterangan: angka yang tidak diikuti huruf menunjukkan berpengaruh tidak nyata dan angka yang diikuti oleh huruf yang sama menunjukkan tidak berbeda nyata dengan uji Tukey $5 \%$
Tabel 2. Hasil uji beda rataan interaksi inokulasi Rhizobium dan pupuk NPK terhadap warna daun

\begin{tabular}{clcc}
\hline \multirow{2}{*}{ Perlakuan } & \multicolumn{3}{c}{ Warna Daun } \\
\cline { 2 - 4 } & \multicolumn{1}{c}{$15 \mathrm{HST}$} & \multicolumn{1}{c}{$30 \mathrm{HST}$} & $45 \mathrm{HST}$ \\
\hline I0P0 & $361,667 \mathrm{a}$ & $7732,250 \mathrm{~b}$ & 7733,000 \\
I0P1 & $361,667 \mathrm{a}$ & $7735,667 \mathrm{~b}$ & 7733,000 \\
I0P2 & $7487,000 \mathrm{~b}$ & $7738,000 \mathrm{~b}$ & 7735,000 \\
I1P0 & $359,000 \mathrm{a}$ & $7737,500 \mathrm{~b}$ & 7730,667 \\
I1P1 & $7487,000 \mathrm{~b}$ & $7734,667 \mathrm{~b}$ & 7733,000 \\
I1P2 & $359,000 \mathrm{a}$ & $7738,000 \mathrm{~b}$ & 7738,000 \\
I2P0 & $361,333 \mathrm{a}$ & $7739,000 \mathrm{~b}$ & 7735,333 \\
I2P1 & $362,000 \mathrm{a}$ & $7739,000 \mathrm{~b}$ & 7733,000 \\
I2P2 & $363,333 \mathrm{a}$ & $7739,000 \mathrm{~b}$ & 7728,000 \\
I3P0 & $7487,000 \mathrm{~b}$ & $7735,333 \mathrm{~b}$ & 7728,000 \\
I3P1 & $7487,000 \mathrm{~b}$ & $7487,000 \mathrm{a}$ & 7736,000 \\
I3P2 & $7488,000 \mathrm{~b}$ & $7735,000 \mathrm{~b}$ & 7730,000 \\
\hline
\end{tabular}

Keterangan: angka yang tidak diikuti huruf menunjukkan berpengaruh tidak nyata dan angka yang diikuti oleh huruf yang sama menunjukkan tidak berbeda nyata dengan uji Tukey $5 \%$.

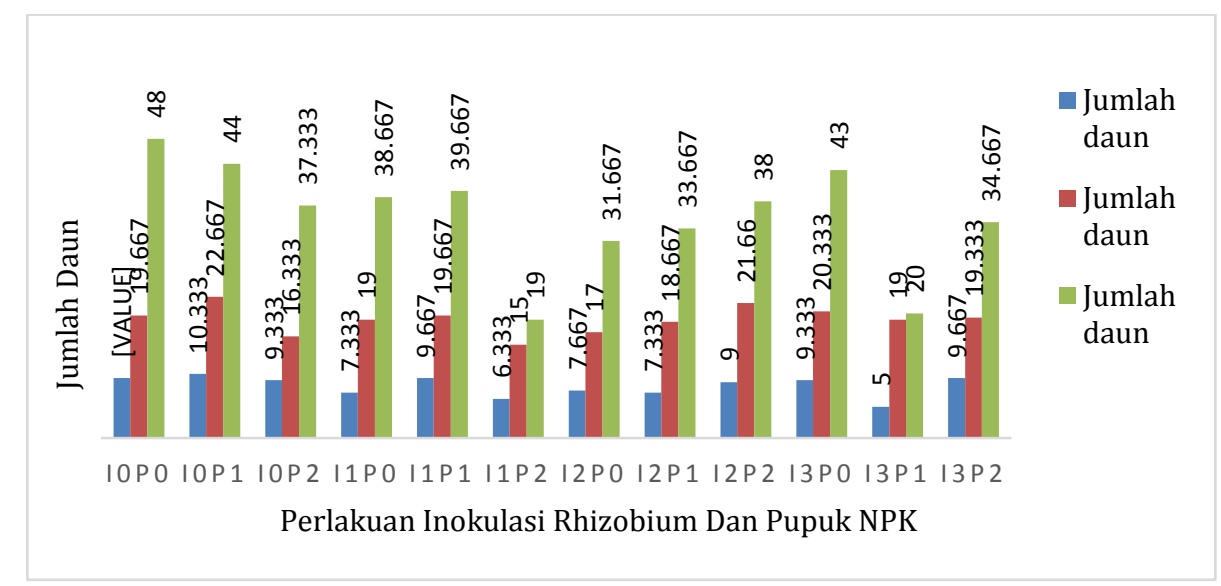

Gambar 1. Pengaruh pemberian Inokulasi Rhizobium dan Pupuk NPK terhadap Jumlah Daun 15, 30, 45 HST

\section{Tinggi Tanaman}

Hasil pengamatan setelah dianalisis secara statistik menunjukkan tidak berpengaruh nyata perlakuan dosis inokulasi Rhizobium dan pupuk NPK terhadap tinggi tanaman pada 15, 30, 40 HST. Tetapi interaksi antar perlakuan dosis inokulasi Rhizobium dan pupuk NPK juga memberikan pengaruh nyata pada $15,30,45$ HST (Tabel 3).

Gambar 3. menunjukkan bahwa pada 15, 30 dan 45 HST, tinggi tanaman mengalami kenaikan. Pada 15 HST tinggi tanaman tertinggi pada kombinasi taraf perlakuan IOP1 $(17,133$ $\mathrm{cm}), 30$ HST tertinggi pada kombinasi IOP2 $(18,000 \mathrm{~cm})$, dan pada 45 HST tertinggi pada kombinasi I3P1 $(20,300 \mathrm{~cm})$.

\section{Jumlah Cabang}

Tabel 4 menunjukkan perlakuan dosis inokulasi Rhizobium, pupuk NPK dan interaksi terhadap jumlah cabang pada 15, 30, 40 HST tidak berpengaruh nyata. Perlakuan inokulasi Rhizobim, pupuk NPK dan interaksi kedua perlakuan tidak berpengaruh nyata terhadap jumlah cabang tanaman kedelai (Gambar 4). 


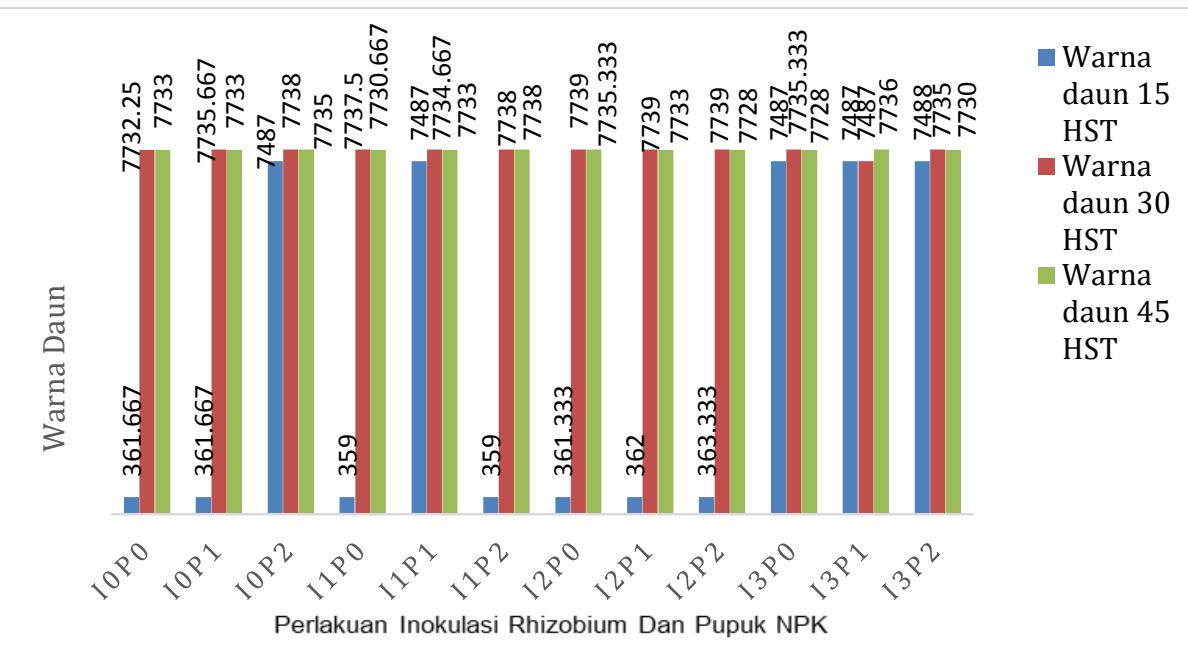

Gambar 2. Pengaruh pemberian Inokulasi Rhizobium dan pupuk NPK terhadap Warna Daun 15, 30, 45 HST

Tabel 3. Hasil uji beda rataan interaksi inokulasi Rhizobium dan upuk NPK terhadap tinggi tanaman

\begin{tabular}{clll}
\hline \multirow{2}{*}{ Perlakuan } & \multicolumn{3}{c}{ Tinggi Tanaman } \\
\cline { 2 - 4 } & \multicolumn{1}{c}{$15 \mathrm{HST}$} & \multicolumn{1}{c}{$30 \mathrm{HST}$} & \multicolumn{1}{c}{$45 \mathrm{HST}$} \\
\hline I0P0 & $14,633 \mathrm{ab}$ & $16,433 \mathrm{ab}$ & $17,033 \mathrm{ab}$ \\
I0P1 & $17,133 \mathrm{~b}$ & $18,267 \mathrm{~b}$ & $19,000 \mathrm{ab}$ \\
I0P2 & $16,867 \mathrm{~b}$ & $18,800 \mathrm{~b}$ & $19,967 \mathrm{~b}$ \\
I1P0 & $15,400 \mathrm{ab}$ & $17,067 \mathrm{ab}$ & $17,967 \mathrm{ab}$ \\
I1P1 & $13,433 \mathrm{ab}$ & $15,533 \mathrm{ab}$ & $16,967 \mathrm{ab}$ \\
I1P2 & $17,033 \mathrm{~b}$ & $18,600 \mathrm{~b}$ & $19,167 \mathrm{ab}$ \\
I2P0 & $16,567 \mathrm{~b}$ & $18,500 \mathrm{~b}$ & $20,033 \mathrm{~b}$ \\
I2P1 & $13,167 \mathrm{ab}$ & $15,400 \mathrm{ab}$ & $17,867 \mathrm{ab}$ \\
I2P2 & $14,667 \mathrm{ab}$ & $16,733 \mathrm{ab}$ & $19,133 \mathrm{ab}$ \\
I3P0 & $11,733 \mathrm{a}$ & $13,167 \mathrm{a}$ & $14,567 \mathrm{a}$ \\
I3P1 & $15,700 \mathrm{ab}$ & $17,900 \mathrm{ab}$ & $20,300 \mathrm{~b}$ \\
I3P2 & $15,633 \mathrm{ab}$ & $17,600 \mathrm{ab}$ & $19,300 \mathrm{~b}$ \\
\hline
\end{tabular}

Keterangan: angka yang tidak diikuti huruf menunjukkan berpengaruh tidak nyata dan angka yang diikuti oleh huruf yang sama menunjukkan tidak berbeda nyata dengan uji Tukey $5 \%$.

Menurut Yulianingsih (2014), hal ini menunjukkan bahwa unsur hara yang terdapat pada seluruh perlakuan tidak tersedia bagi cabang tanaman kedelai. Nitrogen merupakan salah satu unsur hara yang dapat mempengaruhi pertumbuhan cabang, kurangnya unsur $\mathrm{N}$ yang tersedia bagi tanamn dapat menyebabkan pertumbuhan terganggu. Unsur hara $\mathrm{N}$ sendiri berfungsi untuk merangsang pertumbuhan secara keseluruhan,
Tabel 4. Hasil uji beda rataan interaksi inokulasi Rhizobium dan upuk NPK terhadap jumlah cabang

\begin{tabular}{cccc}
\hline \multirow{2}{*}{ Perlakuan } & \multicolumn{3}{c}{ Jumlah cabang } \\
\cline { 2 - 4 } & 15 HST & 30 HST & 45 HST \\
\hline I0P0 & 2,333 & 3,333 & 8,000 \\
I0P1 & 2,333 & 3,667 & 6,333 \\
I0P2 & 1,667 & 2,000 & 6,667 \\
I1P0 & 2,000 & 2,667 & 7,000 \\
I1P1 & 2,000 & 3,333 & 7,333 \\
I1P2 & 1,333 & 2,333 & 6,333 \\
I2P0 & 2,000 & 2,667 & 6,667 \\
I2P1 & 2,000 & 3,667 & 7,333 \\
I2P2 & 1,667 & 2,667 & 7,333 \\
I3P0 & 2,333 & 3,333 & 6,667 \\
I3P1 & 2,000 & 3,000 & 7,000 \\
I3P2 & 1,667 & 3,333 & 6,333 \\
\hline Keterangan: & angka yang & tidak diikuti & huruf \\
menunjukkan berpengaruh tidak nyata dan angka & yang diikuti oleh huruf yang sama menunjukkan tidak \\
berbeda nyata dengan uji Tukey $5 \%$.
\end{tabular}

khususnya daun, batang dan cabang. Maka dibutuhan jumlah yang besar terutama pada saat pertumbuhan vegetatif.

\section{Jumlah Nodul Akar}

Tabel 5 menunjukkan bahwa interaksi antar perlakuan dosis inokulasi Rhizobium dan pupuk NPK memberikan pengaruh nyata terhadap jumlah nodul akar pada 60 HST (Gambar 5). 


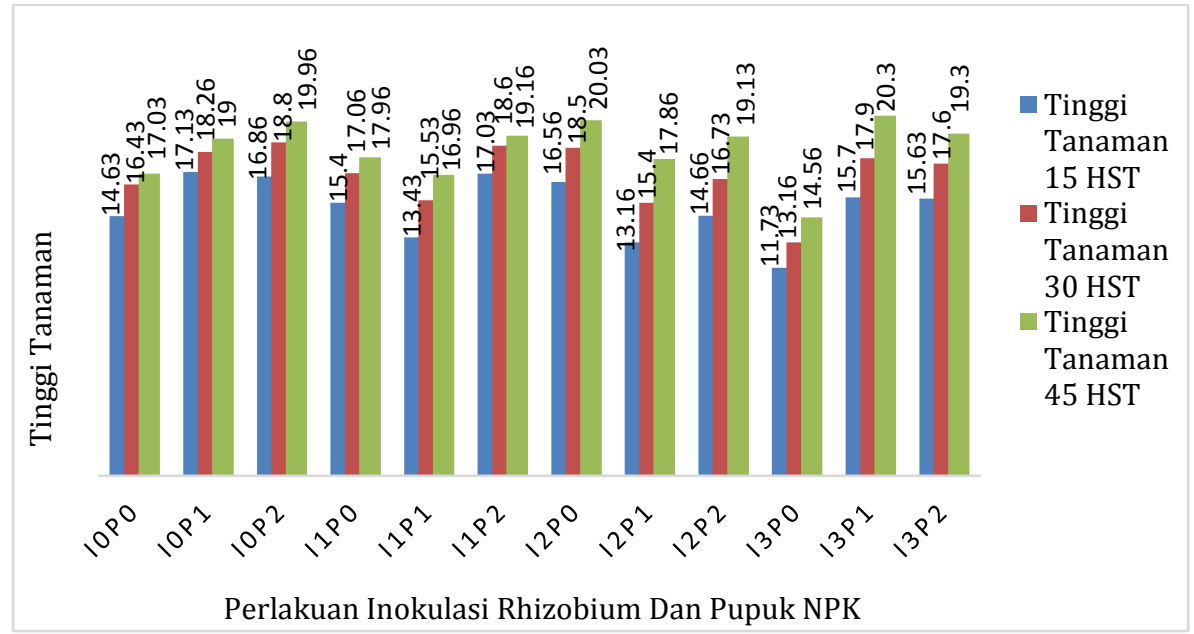

Gambar 3. Pengaruh pemberian Inokulasi Rhizobium dan pupuk NPK terhadap Tinggi Tanaman 15, 30, 45 HST.

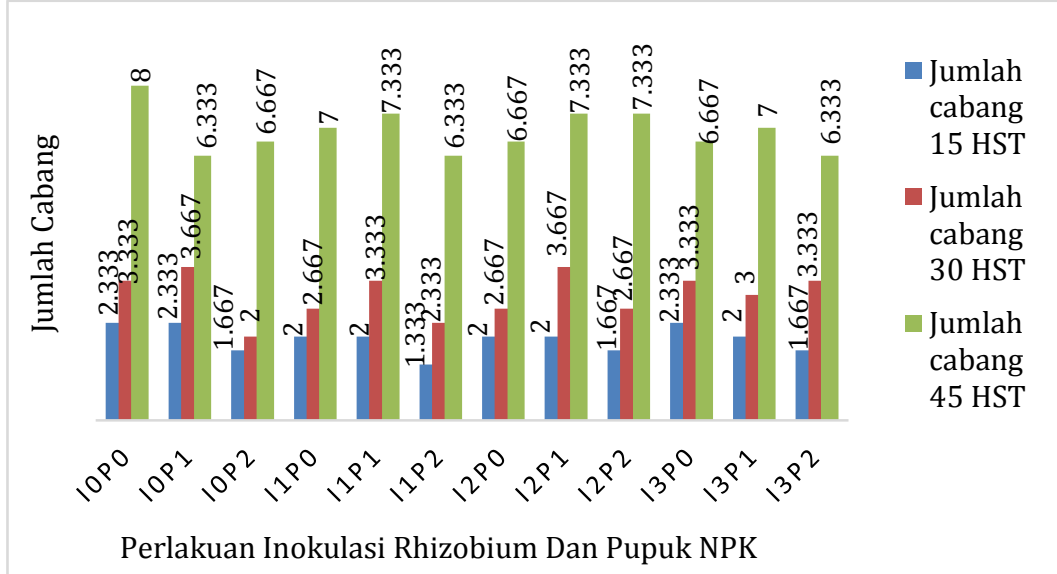

Gambar 4. Pengaruh pemberian Inokulasi Rhizobium dan pupuk NPK terhadap Jumlah Cabang 15, 30, 45 HST.

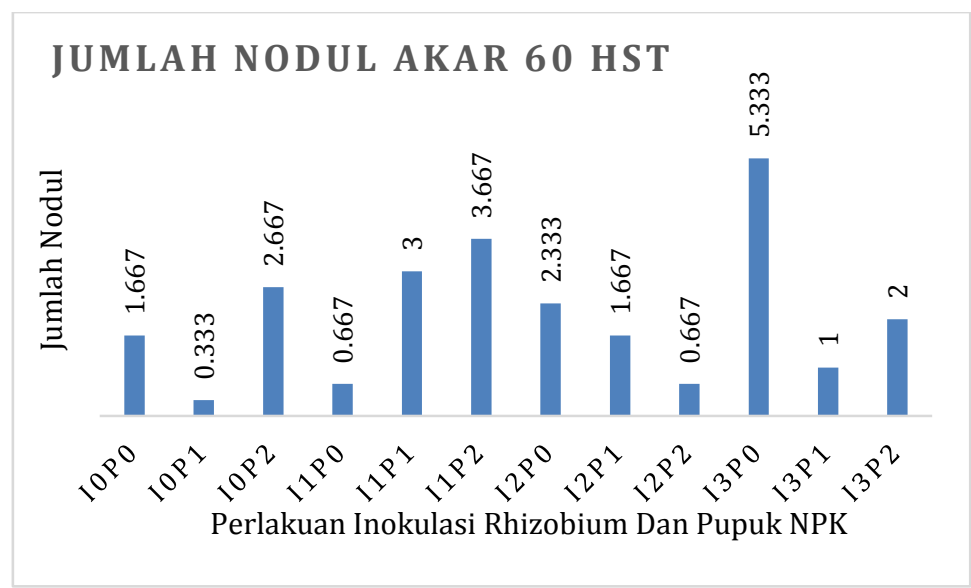

Gambar 5. Pengaruh pemberian Inokulasi Rhizobium dan pupuk NPK terhadap Jumlah Nodul Akar 60 HST. 
Tabel 5. Hasil uji beda rataan interaksi inokulasi Rhizobium dan upuk NPK terhadap jumlah nodul akar

\begin{tabular}{cc}
\hline Perlakuan & Jumlah Nodul Akar 60 HST \\
\hline I0P0 & $1,667 \mathrm{a}$ \\
I0P1 & $0,333 \mathrm{a}$ \\
I0P2 & $2,667 \mathrm{a}$ \\
I1P0 & $0,667 \mathrm{a}$ \\
I1P1 & $3,000 \mathrm{a}$ \\
I1P2 & $3,667 \mathrm{a}$ \\
I2P0 & $2,333 \mathrm{a}$ \\
I2P1 & $1,667 \mathrm{a}$ \\
I2P2 & $0,667 \mathrm{a}$ \\
I3P0 & $5,333 \mathrm{a}$ \\
I3P1 & $1,000 \mathrm{a}$ \\
I3P2 & $2,000 \mathrm{a}$ \\
\hline Keterangan: angka yang tidak dikuti huruf \\
menunjukkan berpengaruh tidak nyata dan angka \\
yang diikuti oleh huruf yang sama menunjukkan tidak \\
berbeda nyata dengan uji Tukey $5 \%$.
\end{tabular}

Tabel 6. Hasil uji beda rataan interaksi inokulasi Rhizobium dan upuk NPK terhadap berat nodul akar

\begin{tabular}{cc}
\hline Perlakuan & Berat Nodul Akar 60 HST \\
\hline I0P0 & 0,077 \\
I0P1 & 0,030 \\
I0P2 & 0,130 \\
I1P0 & 0,027 \\
I1P1 & 0,070 \\
I1P2 & 0,087 \\
I2P0 & 0,110 \\
I2P1 & 0,037 \\
I2P2 & 0,020 \\
I3P0 & 0,150 \\
I3P1 & 0,047 \\
I3P2 & 0,057 \\
\hline Keterangan: angka yang tidak dikuti huruf \\
menunjukkan berpengaruh tidak nyata dan angka \\
yang diikuti oleh huruf yang sama menunjukkan tidak \\
berbeda nyata dengan uji Tukey $5 \%$.
\end{tabular}

\section{Berat Nodul Akar 60 HST

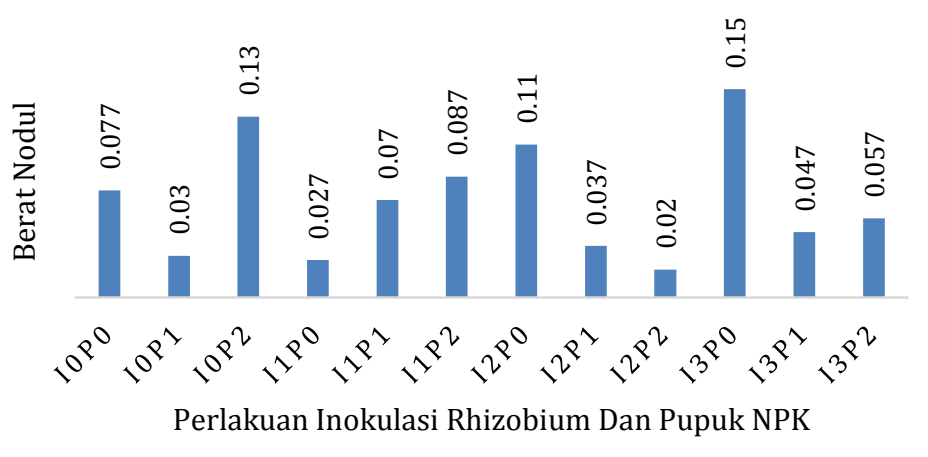

Gambar 6. Pengaruh pemberian Inokulasi Rhizobium dan pupuk NPK terhadap Berat Nodul Akar 60 HST

\section{Berat Nodul Akar}

Tabel 6 menunjukkan bahwa perlakuan dosis inokulasi Rhizobium, pupuk NPK dan interaksi keduanya terhadap berat nodul akar pada 60 HST tidak berpengaruh nyata (Gambar 6).

\section{Pengaruh Inokulasi Rhizobium Terhadap Pertumbuhan Tanaman Kedelai (G. max) Varietas Anjasmoro}

Berdasarkan data pengamatan dan hasil analisis maka diperoleh bahwa inokulasi Rhizobium berpengaruh nyata terhadap jumlah daun pada 45 HST dan warna daun 15, 30 HST. Berpengaruh tidak nyata terhadap jumlah daun
15, 30 HST, warna daun 45 HST, tinggi tanaman, jumlah cabang, jumlah nodul akar dan berat nodul akar 15, 30 dan 45 HST.

Inokulasi Rhizobium memberikan pengaruh yang berbeda nyata terhadap warna daun, yaitu perlakuan I3 yaitu dosis $9 \mathrm{~g} / \mathrm{kg}$ benih. Pada awal pertumbuhan (10-15 HST) merupakan indikasi efektivitas bakteri Rhizobium terhadap perbedaan warna hijau daun (Silalahi 2009). Nitrogen merupakan salah satu unsur hara yang dibutuhkan oleh seluruh tanaman termasuk tanaman kedelai, unsur ini digunakan untuk pertumbuhan dan produksi yang optimal. Nitrogen sangat dibutuhkan untuk daun tanaman sehingga jika unsur $\mathrm{N}$ tercukupi 
maka daun tanaman akan menjadi lebih lebar, berwarna lebih hijau dan lebih berkualitas. Warna daun menjadi indikator status $\mathrm{N}$ tanaman yang berkaitan erat dengan tingkat fotosintesis pada daun. Jika tanaman mengalami defisiensi $\mathrm{N}$ maka warna daun akan memudar dan akhirnya menguning (Ginting 2017).

Penelitian tentang inokulasi Rhizobium pada tanaman leguminosa termasuk salah satunya yaitu tanaman kedelai tidak selalu memberikan hasil yang baik, tidak selalu memberikan pengaruh yang nyata pada pertumbuhan tanaman, bahkan sering mengalami kegagalan. Ada beberapa faktor yang kemungkinan menyebabkan hal ini terjadi, antara lain yaitu rendahnya kemampuan bakteri inokulan untuk bersaing dengan bakteri indigenous (bakteri alami) dalam menginfeksi akar. Faktor lain yang mempengaruhi perkembangan dan aktifitas Rhizobium di dalam tanah yaitu kandungan bahan organik, kelembaban, aerasi, suhu, kemasaman tanah, suplai hara organik, jenis tanah dan presentase pasir serta liat. Penurunan populasi Rhizobium pada tanah melalui inokulasi legin lebih besar dibandingkan dengan perlakuan tanpa legin. Keadaan ini menunjukkan bahwa daya adaptasi Rhizobium inokulan (mikroorganisme masukan) lebih rendah dibandingkan dengan Rhizobia alami (Armiadi 2009).

Menurut Risnawati (2010), dalam hal pengikatan Nitrogen bebas, inokulasi Rhizobium yang diberikan terkadang tidak menunjukkan pengaruh yang positif. Hal ini dapat disebabkan oleh beberapa faktor, yaitu jumlah Rhizobium di dalam inokulum tidak memadai, Rhizobium tidak efektif untuk varietas tertentu, dan metode inokulasi yang digunakan tidak tepat. Pembentukan bintil akar yang baik dari hasil penambatan $\mathrm{N}$ pada akar tanaman legum merupakan suatu rangkaian yang sangat kompleks dari proses fisiologis yang melibatkan interaksi antara tanaman inang dengan inokulum. Beberapa isolat Rhizobium yang berbeda menyebabkan kemampuan memfiksasi Nitrogen yang berbeda pula. Inokulasi Rhizobium pada tanaman kacang-kacangan menunjukkan perbedaan kecocokan suatu strain Rhizobium, yang dapat dilihat dari kemampuan menginfeksi tanaman inang, kemampuan bersimbiosis dalam menambat $\mathrm{N}$ udara serta tanggapan pertumbuhan tanaman inang itu sendiri.

Berat nodul akar diamati pada 60 HST dan setelah analisis secara statistik tidak memberikan pengaruh yang nyata. Hal ini dapat disebabkan bahwa nodul yang sudah berumur 60 HST sudah tidak dapat bekerja dengan maksimal. Pembentukan bintil akar baru mulai sekitar 15-20 HST, dan pengikatan Nitrogen bebas dari udara baru aktif setelah tanaman mencapai umur sekitar 3-4 minggu / 30 HST. Jumlah Nitrogen yang difiksasi oleh bakteri Rhizobium semakin meningkat selama periode pembungaan (vase vegetatif) dan mencapai maksimum pada masa akhir pembungaan serta mengalami penurunan pada proses pengisian polong (Silalahi 2009).

Kemampuan bakteri Rhizobium memfiksasi Nitrogen akan bertambah seiring dengan bertambahnya umur tanaman kedelai, tetapi maksimal sampai akhir masa berbunga atau mulai pembentukan biji. Setalah masa pembentukan biji ini kemampuan memfiksasi Nitrogen akan menurun bersama dengan semakin banyaknya bintil akar yang tua dan mulai luruh (Adisarwanto 2009).

Hasil penelitian menunjukkan bahwa penggunaan inokulasi Rhizobium sebanyak 9 $\mathrm{g} / \mathrm{kg}$ benih memberikan pengaruh yang nyata terhadap setiap parameter.

\section{Pengaruh Pemberian Macam Pupuk NPK Terhadap Pertumbuhan Tanaman Kedelai (G. max) Varietas Anjasmoro}

Berdasarkan data pengamatan dan hasil analisis secara statistika maka diperoleh bahwa pemberian dua macam pupuk NPK yaitu pupuk NPK padat dan pupuk NPK cair hanya memberikan pengaruh nyata pada warna daun. Perlakuan ini berbeda nyata pada 15 dan 30 HST terhadap warna daun. Sedangkan pada parameter lain, yaitu jumlah daun, tinggi tanaman, jumlah cabang, jumlah nodul akar dan berat nodul akar perlakuan pupuk NPK tidak 
berpengaruh nyata. Warna daun yang baik terdapat pada perlakuan P2 (pupuk cair).

Pada fase vegetatif pertumbuhan kedelai dapat meningkat cepat, yaitu pada 28-35 HST dan pertumbuhannya melambat ada saat tanaman mulai berbunga yaitu pada umur 35 HST. Tanaman kurang merespon terhadap unsur hara yang diberikan, hal ini disebabkan karena hara di dalam tanah belum mampu menyuplai hara sesuai kebutuhan tanaman, terutama untuk mempercepat petumbuhan tanaman. Kurangnya efisiensi beberapa unsur hara pada tanaman juga dapat terjadi jika kekurangan atau kelebihan unsur hara (Palobo et al. 2016).

Unsur hara $\mathrm{N}$ yang diberikan pada tanaman akan merangsang pertumbuhan vegetatif, khususnya pada daun dan jumlah anakan tanaman. Salah satu fungsi Nitrogen yaitu sebagai bahan baku penyusun klorofil pada proses fotosintesis. Setelah fotosintesis terjadi maka tanaman akan mentranslokasikan sebagian besar cadangan makanannya ke bagian organ vegetatif tanaman. Tidak maksimalnya pertumbuhan tanaman diduga unsur hara yang dibutuhkan tidak tercukupi dengan baik terutama unsur hara N (Yulianingsih 2014).

Pada tanaman legum, unsur $P$ berfungsi untuk merangsang perkembangan akar sehingga tanaman akan lebih tahan terhadap kekeringan dan dapat mempercepat masa panen. $\mathrm{P}$ yang diserap oleh akar kemudian disebaran ke daun, batang, tangkai dan biji. Unsur hara P berfungsi dalam ketegaran daun tanaman agar tidak gugur. Daun tanaman yang kekurangan unsur $\mathrm{P}$ akan berubah kecoklatan dan dapat gugur lebih awal. Fungsi $\mathrm{P}$ dalam tanaman juga dapat mempercepat dan memperkuat pertumbuhan tanaman muda menjadi dewasa (Silalahi 2009; Ginting 2017).

Tanaman kedelai membutuhkan unsur Kalium yang seimbang. Berfungsi pula sebagai katalisator dan memiliki tugas membongkar dan menyusun karbohidrat, sehingga apabila tanaman kekurangan unsur Kalium maka proses fotosintesis dan respirasi akan terhambat. Kegiatan fotosintesis dapat menurun jika kandungan Kalium rendah, karena Kalium memiliki peran dalam proses sintesis karbohidrat, lemak dan fotosintesis. Maka jika proses fotosintesis menurun akan mengurangi penyaluran karbohidrat sehingga hasil tanaman dan kualitasnya menjadi rendah. Kalium dapat menambah ketahanan tanaman terhadap penyakit dan menghalangi efek rebah tanaman (Fuadi 2013; Hendrival et al. 2014; Rukmi 2009).

Perlakuan pemupukan tidak selalu memberikan pengaruh yang nyata pada pertumbuhan tanaman. Hal ini diduga karena hara di dalam tanah telah mampu memberikan suplai hara sesuai dengan kebutuhan tanaman. Perlakuan pemupukan yang berbeda tidak memberikan respon yang cukup nyata pada pertumbuhan tanaman, hal ini dapat disebabkan karena adanya ketersediaan hara yang cukup di dalam tanah sebelum penanaman. Faktor lain yang dapat menyebabkan tidak adanya pengaruh pada perlakuan pemupukan yaitu diduga karena kesuburan tanah sudah cukup (Fitriesa et al. 2017).

\section{Interaksi Inokulasi Rhizobium dan Macam Pupuk NPK Yang Mempengaruhi Pertumbuhan Tanaman Kedelai (G. Max) Varietas Anjasmoro}

Berdasarkan data pengamatan dan hasil analisis diperoleh bahwa ada interaksi antara pemberian perlakuan inokulasi Rhizobium dan macam pupuk NPK yang memberikan pengaruh yang nyata terhadap jumlah daun, warna daun 15, 30 HST, tinggi tanaman 15, 30 HST dan jumlah nodul akar 60 HST, dan tidak berpengaruh nyata terhadap warna daun 45 HST, tinggi tanaman 45 HST, jumlah cabang dan berat nodul akar.

Pada interaksi ini warna daun dan jumlah nodul akar dapat memberikan pengaruh yang nyata pada perlakuan I3P0 (9 gram Rhizobium dan tanpa pupuk NPK). Menurut Ginting (2017), keberadaan unsur $\mathrm{N}$ pada tanaman dapat dilihat dari warna daunnya, dimana ini berkaitan erat dengan tingkat fotosintesis daun dan produksi tanaman. Sedangkan $\mathrm{N}$ yang tersedia pada tanaman merupakan tambatan $\mathrm{N}$ dari udara 
yang dihasilkan oleh nodul akar yang telah tersisipi bakteri Rhizobium. Tanaman akan tumbuh dengan cepat apabila memiliki ketersediaan $\mathrm{N}$ yang cukup. Nitrogen berperan dalam sintesis protein dan merupakan bagian tak terpisahkan dari molekul klorofil. Maka dari itu dengan adanya jumlah $\mathrm{N}$ yang cukup akan memberikan pertumbuhan vegetatif yang baik dan warna hijau daun yang segar.

Hasil penelitian menunjukkan bahwa interaksi antara perlakuan inokulasi Rhizobium dan macam pupuk NPK berpengaruh nyata terhadap sebagian besar parameter yang diamati. Rhizobium merupakan bakteri yang dapat bersimbiosis dengan tanaman jenis leguminosae salah satunya tanaman kedelai yang dapat mengikat unsur $\mathrm{N}$ di udara untuk persediaan bagi tanaman. Sedangkan pupuk NPK berperan sebagai unsur hara makro yang sangat dibutuhkan oleh tanaman sebagai penunjang pertumbuhannya (Silalahi 2009; Yusuf et al. 2017; Fahmi et al. 2014).

Interaksi antara inokulasi Rhizobium dan pupuk NPK yang memberikan pengaruh terhadap pertumbuhan kedelai karena Rhizobium merupakan bakteri yang dapat bersimbiosis dengan tanaman leguminosae yang dapat mengikat $\mathrm{N}$ di udara yang dibutuhkan oleh tanaman. Bakteri Rhizobium dibentuk di dalam akar tanaman yang dinamakan nodul akar atau bintil akar. Sedangkan unsur P sendiri dibutuhkan untuk merangsang pertumbuhan akar sebagai tempat bakteri ini membentuk bintil akar. Keberadaan unsur $\mathrm{K}$ membantu dalam merangasang pertumbuhan tanaman (Silalahi 2009; Adisarwanto 2009).

Dalam interaksi yang positif, unsur hara $\mathrm{P}$ dan $\mathrm{N}$ memiliki peranan yang berbeda bagi tanaman. Unsur hara $\mathrm{N}$ berperan sebagai penyusun klorofil, protein, asam amino dan senyawa lainnya. Sedangkan hara $\mathrm{P}$ berperan sebagai penyusun fosfolipid nukleoprotein, gula fosfat dan khususnya pada transport dan penyimpanan energi dimana sebagian besar senya tersebut saling melengkapi. Ketersediaan $\mathrm{N}$ di tanah sangat mempengaruhi serapan tanaman terhadap $\mathrm{P}$ begitupun sebaliknya. $\mathrm{N}$ akan menigkatkan pertumbuhan dan perkembangan akar sehingga unsur hara $P$ dapat diserap lebih efektif. $\mathrm{N}$ juga merupakan penyusun utama enzim phosphatase yang terlibat dalam proses mineralisasi $\mathrm{P}$ di tanah (Fahmi et al. 2010).

Secara fisiologis, pemberian unsur hara Kalium dapat meningkatkan jumlah polong dan jumlah biji pada tanaman kedelai, yaitu dengan mekanisme metabolisme karbohidrat dari hasil fotosintesis. Berfungsi dalam pembentukan, pemecahan dan translokasi pati dalam jaringan tanaman serta metabolisme Nitrogen dan sintesis protein (Hendrival et al. 2014).

Pertumbuhan yang baik pada tanaman kedelai terjadi karena adanya keseimbangan jumlah unsur hara yang baik pula. Apabila terjadi kekurangan atau kelebihan unsur hara maka akan mengakibatkan efek buruk pada tanaman. Pada tanaman, unsur Kalium dapat menambah ketahanan tanaman terhadap penyakit tertentu, Kalium cenderung menghalangi efek rebah tanaman dan bahkan melawan efek buruk yang disebabkan oleh terlalu banyaknya unsur Nitrogen. Kalium juga bekerja berlawanan dengan pengaruh kematangan yang dipercepat oleh Fosfor (Rukmi 2009).

\section{Simpulan}

Dosis Rhizobium yang dapat mempengaruhi pertumbuhan kedelai yaitu dosis 9 gram/kg benih, dan berpengaruh nyata terhadap jumlah daun dan warna daun. Namun tidak berpengaruh nyata terhadap tinggi tanaman, jumlah cabang, jumlah nodul akar dan berat nodul akar jenis pupuk NPK yang dapat mempengaruhi pertumbuhan kedelai yaitu pupuk NPK cair. Pupuk NPK cair berpengaruh nyata terhadap warna daun, namun tidak berpengaruh nyata terhadap jumlah daun, tinggi tanaman, jumlah cabang, jumlah nodul akar dan berat nodul akar. Interaksi kedua perlakuan berpengaruh nyata terhadap jumlah daun, warna daun, tinggi tanaman dan jumlah nodul akar. Namun interaksi tidak berpengaruh nyata terhadap jumlah cabang dan berat nodul akar. 


\section{Daftar Pustaka}

Adisarwanto, T. 2009. Kedelai (Budidaya dengan Pemupukan yang Efektif dan Pengoptimalan Bintil Akar), Cetakan ke-IV. Jakarta: Penebar Swadaya.

Armiadi. 2009. Penambatan nitrogen secara biologis pada tanaman Leguminosa. Wartazoa. 19(1): 23-30.

Fahmi A, Syamsudin, Utami S. N. H, Radjagukguk B. 2010. Pengaruh interaksi hara nitrogen dan fosfor terhadap pertumbuhan tanaman jagung (Zea mays L.). Berita Biologi. 10(3): 297-304.

Fahmi N, Syamsuddin, Marliah A. 2014. Pengaruh pupuk organik dan anorganik terhadap pertumbuhan dan hasil kedelai (Glycine $\max$ (L.) Merril). J. Floratek. 9: 53-62.

Fitriana D. A, Islami T, Sugito Y. 2014. Pengaruh dosis Rhizobium serta macam pupuk kandang terhadap pertumbuhan dan hasil tanaman kacang tanah (Arachis hypogaea L.) varietas kancil. Jurnal Produksi Tanaman. 3(7): 547-555.

Fitriesa S, Sari M, Suhartanto M. R. 2017. Pengaruh pemupukan N, P, dan $\mathrm{K}$ pada dua varietas benih kedelai (Glycine max (L) Merr.) terhadap kandungan antosianin dan hubungannya dengan vigor benih. Bul. Agrohorti. 5(1): 117-125.

Fuadi. 2013. Pengaruh Dosis Kalium Dan Phosfat Terhadap Pertumbuhan Dan Produksi Tanaman Kedelai (Glycine max (L) Merril). Skripsi. Aceh Barat: Universitas Teuku Umar Meulaboh.

Ginting A. K. 2017. Pengaruh Pemberian Nitrogen Dan Fosfor Terhadap Pertumbuhan Legum Calopogonium Mucunoides, Centrosema Pubescens Dan Arachis Pintoi. Skripsi. Jambi: Universitas Jambi.

Hendrival L, Idawati. 2014. Pengaruh pemupukan kalium terhadap perkembangan populasi kutu daun (Aphis glycines Matsumura) dan hasil kedelai. Jurnal Floratek. 9: 83-92.

Hendriyanto M. F, Suharjono, Rahayu S. 2017. Aplikasi inokulasi Rhizobium dan pupuk SP-36 terhadap produksi dan mutu benih kedelai (Glycine $\max$ (L.) Merrill) Var. Dering. Agriprima. 1(1): 94-103.

Jumakir, Endrizal. 2014. Produktivitas Kedelai Varietas Anjasmoro Pada Kondisi Cekaman Kekeringan Di Provinsi Jambi. Prosiding Seminar Hasil Penelitian Tanaman Aneka Kacang dan Umbi 282287.

Misran. 2013. Studi Penggunaan pupuk hayati pada tanaman kedelai. Jurnal Penelitian Pertanian Terapan. 13(3): 206-210.

Palobo F, Ayakeding E, Nunuela M, Marwoto. 2016. Pengaruh waktu aplikasi pupuk npk phonska terhadap pertumbuhan dan hasil kedelai. Prosiding Seminar Hasil Penelitian Tanaman Aneka Kacang dan Umbi: 198-206.

Risnawati. 2010. Pengaruh Pemberian Pupuk Urea Dan Beberapa Formula Pupuk Hayati Rhizobium Terhadap Pertumbuhan Dan Hasil Kedelai (Glycine Max (L.) Merril) Di Tanah Masam Ultisol. Skripsi. Malang: Universitas Islam Negeri Maulana Malik Ibrahim Malang.

Rukmi. 2009. Pengaruh Pemupukan Kalium Dan Fosfat Terhadap Pertumbuhan Dan Hasil Kedelai. 1-13.

Silalahi H. 2009. Pengaruh Inokulasi Rhizobium Dan Pupuk Fosfat Terhadap Pertumbuhan Dan Produksi Kedelai (Glycine max L. Merril). Skripsi. Medan: Universitas Sumatera Utara.

Yulianingsih, Astina. 2014. Efisiensi Penggunaan Pupuk Anorganik Dengan Aplikasi Effective Microorganism 10 (EM10) Pada Tanaman Kedelai (Glycine max (L) Merill). Skrpsi. Jakarta: Universitas Islam Negeri Syarif Hidayatullah. 
Yusuf F, Hadie J, Yusran M. F. H. 2017. Respon tanaman kedelai terhadap serapan hara NPK pupuk daun yang diberikan melalui akar dan daun pada tanah gambut dan podsolik. Jurnal Daun. 4(1): 17-28. 